\title{
"HEARTLESS, ROBOTIC APOLOGIES": INDIGENIZING TORONTO EDUCATION
}

\section{LEIF V. FITZSIMMONS FREY}

\section{ABSTRACT}

This paper explores the ritual performances of reading the treaty acknowledgement every morning in my school board, in contrast to and in conjunction with the playing of the national anthem. The paper uses a survey I conducted in my middle school, my lived experiences in the school system, and draws on the ideas of Jill Carter, Leanne Betasamosake Simpson, Angela Sweigart-Gallagher, and Chelsea Vowel to inform a critical discussion about these performances and the way they provide an example of the failings and limitations of the school board's current approach to reconciliation.

\section{KEYWORDS}

indigenous, indigenizing, First Nations, grades 7-8, truth and reconciliation

Author's Note: I would like to acknowledge my mother's invaluable help with this article. She spotted the call for submissions in the first place, provided comments, and proofread my work.

\section{N T RODUC T ION}

The morning bell rings. Students rush into the hallways. Lockers are opened and slammed shut. Teachers attempt to achieve some control over the unfolding chaos. Suddenly, the national anthem plays over the public address system. Everyone freezes and falls silent.

Did anyone notice the first ritual of the day?

My Canadian school board has instituted some curriculum changes in response to the Calls to Action released by the Truth and Reconciliation Commission of Canada a few years ago. I conducted an anonymous survey of students in my school to gauge whether these curriculum changes were having an effect on student learning. I also asked questions about the way our school board is implementing reconciliation through a daily treaty acknowledgment ritual. In this paper, I assert that the treaty acknowledgment represents a superficial performance, rather than a meaningful step towards Indigenous-settler reconciliation.

I am a settler living and going to school in the Dish with One Spoon Wampum Belt Covenant Territory, and I was born in Treaty 6 Territory. As a settler student, I have been very interested in the Truth and Reconciliation Commission Calls to Action, especially those related to education, and wanted to examine their effects on my own school a few years after being instituted. I approach my discussion from the position of a white, male, cisgender, heterosexual, Christian, middle-income youth.

In 2015, the Truth and Reconciliation Commission of Canada (TRC) released 94 Calls 
to Action (TRC, 2015a). They included calls to action on child welfare, health, justice, amendments to laws, and education. The objective of the Truth and Reconciliation Commission of Canada is to "guide and inspire Aboriginal peoples and Canadians in a process of reconciliation and renewed relationships that are based on mutual understanding and respect" (TRC, 2015b).

My school board (a public school board in the Greater Toronto Area) has already mandated articles 62 and 63. ${ }^{1}$ Article 63.iii of the TRC demands that schools work towards "...Building student capacity for intercultural understanding, empathy, and mutual respect." Every morning, in my school board, we listen to "O Canada" over the PA system, and someone reads the treaty acknowledgement, which acknowledges the historical and enduring presence of specific Indigenous peoples, and locates the school in the area of a particular colonial land transfer. In this paper, I assert that the ritualistic performance of reading the treaty acknowledgment does not contribute meaningfully to fostering "understanding, empathy, and mutual respect" among Indigenous and settler students.

At my school, the reading of the treaty acknowledgement seems to be in response to the TRC Calls to Action. It only started recently, and appears to be an attempt by my school board to Indigenize education and spaces of education. I will be using an older definition of "Indigenization," which is the one currently being used by my school board. According to this definition, Indigenization involves creating changes in schools so that the "values, principles, and modes of organization and behavior of [Indigenous peoples] are respected in, and hopefully even integrated into, the larger system of structures and processes that make up the [school] itself" (Mihesuah \& Wilson, 2004, p. 88).

1. These articles state:

62. We call upon the federal, provincial, and territorial governments, in consultation and collaboration with survivors, Aboriginal peoples, and educators, to: i. Make age-appropriate curriculum on residential schools, Treaties, and Aboriginal peoples' historical and contemporary contributions to Canada a mandatory education requirement for Kindergarten to Grade Twelve students. ii. Provide the necessary funding to post-secondary institutions to educate teachers on how to integrate Indigenous knowledge and teaching methods into classrooms. iii. Provide the necessary funding to Aboriginal schools to utilize Indigenous knowledge and teaching methods in classrooms. iv. Establish senior-level positions in government at the assistant deputy minister level or higher dedicated to Aboriginal content in education.

63. We call upon the Council of Ministers of Education, Canada to maintain an annual commitment to Aboriginal education issues, including: i.

Developing and implementing Kindergarten to Grade Twelve curriculum and learning resources on Aboriginal peoples in Canadian history, and the history and legacy of residential schools. ii. Sharing information and best practices on teaching curriculum related to residential schools and Aboriginal history. iii. Building student capacity for intercultural understanding, empathy, and mutual respect. iv. Identifying teacher-training needs relating to the above. 
I am using the idea of Indigenization, rather than decolonization. Tuck \& Yang (2012) write that decolonization does not "entertain a settler future" (p. 3). It is therefore not really possible for as long as schools remain in any form of settler control. Tuck \& Yang (2012) also write that "Decolonization is not a swappable word for other things we want to do to improve our societies and schools. Decolonization doesn't have a synonym" (p. 3). I am also using the idea of "settler schools" throughout this article. These are schools with a primarily settler student body, teaching staff, and administration, and are designed and administrated from a settler perspective with the intention of teaching settler ideas and values.

My research indicates that the Indigenization of my settler school by the school board is currently not going deep enough. We need, as the TRC recommends, to build "understanding, empathy, and mutual respect" (2015a). We need a lot more than hollow rituals that students do Indigenization of my settler school by the school board is currently not going deep enough.

notunderstand. Infact, Leanne Simpson (2012) asserts that Indigenizing education is not about settlers acknowledging Indigenous people-it is about Indigenous people having control over their own schools. Similarly, Chelsea Vowel (2016) writes that "Indigenous education means Indigenous planning, development, and control" (p. 241). As a starting point, I think that the Indigenization of settler schools requires that school boards hand some control over to Indigenous experts, although what that might look like is up for debate. School boards must consider what it means to be an Indigenous expert, who those people might be, and what kind of powers, privileges, and rights they would have in public schools. Christine Fredrick says that "You cannot just have one Indigenous expert. You need multiple experts in multiple fields" (Fredrick, personal communication).

The morning rituals in my school system (the anthem and the treaty acknowledgement) are part of the "processes that make up the school itself" that Mihesuah \& Wilson (2004) reference. After conducting the survey to determine whether curriculum changes that were influenced by the TRC Calls to Action were having an effect on student learning in my school, I made observations about these rituals that suggest that the daily performance does not hand control of the education space to Indigenous peoples. Furthermore, I question whether it fosters the respect or even recognition that the school board claims to have as a goal. Ultimately, the current mode of performing the ritual, especially as it is paired with the performance of the national anthem, is ineffective and perhaps even counterproductive to reconciliation. The way the ritual is currently conducted in my school may fail to foster respectful relationships between settlers 
and Indigenous peoples, and currently does not contribute at all to student understanding, empathy, and mutual respect.

\section{THE STUDY AND SCHOOL CON TEXT}

I noticed the significance of the performance of the treaty acknowledgement through the surveys I conducted, and through reflections on my own experiences as a grade 7 student in the public school system. My initial survey was designed to evaluate the efficacy of the school board's implementation of the Calls to Action in order to see if they were having an effect on student learning, and if so, how much. The survey was for grades 5-8, but only grade 7 and 8 students responded (27 in total). No one self-identified as First Nations, Inuit, or Métis.

I did some research after I conducted the survey, and I found out that about one in 200 Torontonians identify as Indigenous. There is also a Native Friendship Centre and an Anishinaabe restaurant close to my school, so there is a visible Indigenous presence in my neighbourhood. My small sample size makes statistical analysis inappropriate, so I have done qualitative analysis of the major themes in the responses to the long-answer questions. All quotes I share are verbatim, according to the way they were written and originally spelled. This is important because I want to maintain student voice, as embodied in their exact words. Also, some typos may make the meaning of a student's response ambiguous, and I do not want to impose my own ideas on a quotation.

In my survey I asked students about their knowledge of Indigenous peoples in Canada, and Toronto more specifically; the Truth and Reconciliation Commission; and residential schools. ${ }^{2}$ I also asked about our morning rituals of singing the national anthem and reading the treaty acknowledgement. These questions in particular proved to be very generative. My questions were intentionally broad and open-ended so I could see what people thought was important or relevant.

I view ritualistic activities like the national anthem and

2. In my survey, I also asked questions about decolonization. Before conducting my research, I was under the impression that the terms "Indigenization" and "Decolonization" were interchangeable. I now know that is not the case. Tuck \& Yang (2012) write that "Decolonization is not a swappable term for other things we want to do to improve our societies and schools. Decolonization doesn't have a synonym" (p. 3). They further write that "decolonization is not accountable to settlers, or settler futurity. Decolonization is accountable to Indigenous sovereignty and futurity" ( $p$. 36). For that reason, and informed by my other readings, I stopped using decolonization and I adopted Indigenization for my framework for this discussion. I also make some use of reconciliation frameworks and ideas, primarily because it is the stated goal of the TRC. 
treaty acknowledgment as performance. Performance studies scholars Sweigart-Gallagher \& Lantz (2014) assert that "The unifying factor in engaging I view ritualistic activities like the national anthem and treaty acknowledgement as performance. the collective consciousness is performance. Daily rituals, like reciting pledges and the way we eat or dress... are public performances of nationhood" (p. 2). I think that singing national anthems or reading treaty acknowledgments can also be counted as "public performances of nationhood," where those who partake in the ritual learn, in essence, how to be Canadian. In the context of Indigenizing our schools, this performance can also be seen as teaching settlers how to be respectful of and accountable to Indigenous peoples, aligning with the goals claimed by the school system around the TRC Calls To Action. In this way, the performance can be seen as a public performance of attempts to Indigenize Canadian schools.

Questions about the treaty acknowledgment and the national anthem were included in the survey for a few reasons. I think that these rituals are rather pointless if participants do not know why they do them, but I also think the national anthem and treaty acknowledgment rituals are related, particularly since they are paired every morning. There are connections with our nation, the land that the school is on, and, some would say, nationalism and possibly Indigenization of school spaces.

However, the treaty acknowledgement ritual is not given respect in my school in the same way that the national anthem is. In my school system, students have to stand for the national anthem, but do not stand (or even stop what they are doing) for the reading of the acknowledgment. Although students are required to stand for the anthem, in my experience they sometimes resist the act of standing, presumably as an intentional statement of disrespect or disregard. Even those acts of resistance show that my classmates have absorbed or learned the purpose or meaning of daily performance of the national anthem, at least to some extent. I think that requiring participation in this ritual sends a message that the anthem (and by extension, Canada, the settler state) is important. Not requiring the treaty acknowledgement to be such a shared performance may send a message that it is not an important ritual, or at least not as important as the anthem. In other words, respect for and accountability towards Indigenous people is not as important as national rituals that constitute the settler state. It is worth noting that, in my experience, many teachers do not respect the treaty acknowledgment either, giving students even less reason to notice it or reflect on it. 


\section{DISCUSSION OF FINDINGS}

Although this paper focuses on the performance of the national anthem and the treaty acknowledgement, my survey offers some valuable insights into the knowledge and perspectives of students in my school on Indigenous issues that help to demonstrate the broader context that schools in my school board are operating in. ${ }^{3}$ In this section, I will examine student responses to questions, and their implications with regards to our curriculum and the performative rituals of the national anthem and treaty acknowledgment.

One question I asked was what respondents knew about Indigenous people in Canada. The most prominent theme in the answers was the exploitation of Indigenous people by European settlers. A few examples include: "Canada belonged to them, they were kind to settlers while some of the settlers were unkind to them, Indigenous children were beaten, raped and humiliated at residential schools;" "i know that they were very discriminated against and that they were oppressed for a long time;" and "I know that there are First nations reserves and are poorly treated."

I also asked, "What do you know about residential schools?" Responses indicated that the goal of residential schools was, as one student put it, "[to force] native people to convert to [a European] way of life, religion, and language." There was also mention of the Church or government: "They were schools were most First Nations kids went. The schools were run by teh church. The kids there were ussally very badly treated;" "Residential schools were government-sponsored schools that taught Indigenous children to take part in the EuroCanadian culture." Only one person gave any information that was specific to Toronto: "Spadina Avenue and Davenport Road, David A. Balfour Park in Deer Park and Humber River in Étienne Brûlé Park are all sites where you can learn bout Fiest Nations history." Additionally, respondents seemed to understand Indigenous peoples in an historical context. Indications of an understanding of contemporary Indigenous peoples among students who responded to my survey were almost nonexistent, despite the fact that several Toronto treaty acknowledgments include references to contemporary and enduring Indigenous peoples.

No one talked about present-day Indigenous artists, athletes, culture, government, etc. That they didn't mention these things does not mean that the respondents didn't know

3. For example, some contextual insight into student knowledge is provided by my finding that, while $89 \%$ of respondents said they knew what residential schools were, only $31 \%$ said they knew what decolonization is, and $22 \%$ said they knew what the Truth and Reconciliation Commission is. This is probably because, in my experience, residential schools are covered in the curriculum far more than decolonization or the TRC. 
about them, but it does indicate that they didn't think they were important (or the respondents didn't think I thought they were important). Only two years ago, my fifth-grade teacher taught us about the Two Row Wampum Belt, one of the first treaties between the Iroquois and the British. Our class did a blanket exercise. ${ }^{4}$ We went to a protest about the Canadian government's lack of action on mercury in the water around Grassy Narrows (Grassy Narrows River Run). It's hard not to pay attention at a protest. We admired the youth musicians. ${ }^{5}$ We were serious about supporting the cause. Why didn't this kind of thing find its way into the survey responses? Some people, more cynical than me, would suggest it is because our education system privileges teaching and learning to the test, which means that students don't value what is not tested. Many student responses were vague, considered international contexts and Indigenous people in other nation-states rather than Canadian contexts, provided no specific information, or admitted "I don't know how to explain it." ${ }^{\circ}$ The way survey respondents demonstrate knowledge and understanding (or lack thereof) indicates a serious obstacle to Indigenization in my school board.

Most of the historical narratives which respondents mentioned in the survey frame the white settler as the active party and Indigenous peoples as the passive party - victims and faceless statistics. One respondent described residential schools, for instance, as "Europeans forcing native people to convert to their way of life, religion, and language." Seeing Indigenous people primarily as vanishing/ed or victims is counter to Gerald Vizenor's concept of "survivance," as put to use by Jill Carter. Carter (2015) explains that survivance is an active demonstration of presence-the continuation of native stories, and of living Indigenous people and peoples. Survivance also insists on the possibility of Indigenous futurity (Carter, 2015). Settlers need to believe in Indigenous futurity, and not settler futurity, in order to effectively live in relation, or as Article 63 puts it, with empathy and mutual respect.

4. A role-playing exercise where blankets are used to represent Indigenous land, and folded to represent land thefts. See kairosblanketexercise.org 5. Sharice Bruce, Dylan Fobister, Jimi Fobister, Preston Paul, Darwin Fobister, Janessa Kejick, Damien Kejick, Ashley Fobister, Linda Fobister, Paul Cedric Oteskan, Edmond, Jack, and Josh Bigblood.

6. Several respondents discussed the TRC and decolonization in very broad, international contexts ("the Truth and Reconciliation Commission is a commission tasked with discovering and revealing past wrongdoings by a government, in hope to resolve a conflict left over from the past"; "[Decolonization] means people getting thier rights and freedoms back"). Some did not demonstrate their claimed knowledge, suggesting that they did not have in-depth understanding: ("something with first nations", "I don't know how to explain it"). I believe that this is because residential schools are covered extensively in the curriculum, but in my experience, decolonization and the TRC are lucky to get a passing mention. 
As mentioned, in my public school system, the policy is for all students to first read or listen to the treaty acknowledgement, and second, listen to "O Settlers need to believe in Indigenous Canada" every morning. In futurity, and not settler futurity, in order my survey, I asked questions to effectively live in relation. about why these rituals are done. Major themes of the responses to the treaty acknowledgment question included recognition (e.g., "to recognize that First Nations peoples were the first [inhabitants], but then the Canadian Government took over"); acknowledgment (e.g., "to acknowledge the land that the school grounds are on"); and respect (e.g., "to respect the use of their land"). Only one person said they didn't know why we read the acknowledgment, and responded "IDK" (text speak for "I Don't Know") to everything.

A few responses were also cynical: "Because people constantly feel the need to say heartless, robotic apologies. It would make sense if they meant it." I wonder if the ritual of the treaty acknowledgement in a settler school has the potential to ingrain in participants a sense that the land and Indigenous peoples are important, or if it always just feels like "lip service" or "going through the motions." The school board claims its goals are to enhance student "knowledge, understanding, and mutual respect," but is the morning treaty acknowledgment ritual conducive to that goal? Sweigart-Gallagher \& Lantz (2014) write that "Youth learn to perform national identity and nationalism, through both formal and informal means" (p. 4, emphasis original). Institutionalizing the performance in school is a form of teaching. Reading the treaty acknowledgement each morning is a formal means of performing, not so much national identity and nationalism, but a portrayal of the nation that suggests Canada is innocent, caring, and not responsible for land theft, and that settlers are an inextricable part of the nation's futurity. The school's efforts to Indigenize the education spaces and to perform settler-Indigenous reconciliation in this public way is more about excusing settler atrocities than about effecting change.

The school's efforts to Indigenize the education spaces and to perform settler-Indigenous reconciliation in this public way is more about excusing settler atrocities than about effecting change.

I think that if the majority of settler students do not grapple with what it means to be respectful and accountable to Indigenous survivance with regards to the Acknowledgment, it may defeat the purported purpose of this exercise and ritual. The two rituals (anthem and acknowledgment) are done one after the other, but as I mentioned, an attitude of respect, even 
reverence, is enforced for the national anthem, whereas an attitude of indifference towards the acknowledgment prevails. The performance of the anthem indicates that my school board knows how to make a ritual effective; they simply do not do so for the treaty acknowledgment. The efficacy of a treaty acknowledgement ritual is not sufficient for Indigenization, but respectful performance is, perhaps, a good starting point, and as long as the treaty acknowledgement is performed ineffectively and with indifference, it is an obstacle to Indigenization and positive settler-Indigenous relations, because it sets a tone of indifference and excuses settler wrongs.

The student who referred to the acknowledgment as part of a system of "heartless, robotic apologies" is probably right: the shared performance every morning might be hollow, something that students do mechanically, because it is a required ritual, rather than using the time to think and contemplate on settler wrongs. Some students did use words like respect, recognize, and acknowledge in their responses. These are aspects of the school board's goals for Indigenizing education. But, I think, if students and staff at public schools (or anyone) read the acknowledgment, that they have to say it sincerely, and settlers partaking in the ritual must respond appropriately, with genuine solemnity. It is possible that this sort of bland recitation has some value - we may see that operating with the performance of the national anthem every morning. It could be that students will absorb the ideas inherent in the treaty acknowledgement through a sort of osmosis, hearing it despite not actively thinking about it. Perhaps some, maybe all, of the students can recite the treaty acknowledgment from memory! But recitation does not indicate understanding, empathy, or mutual respect.

In contrast, almost every answer to "Why do we sing the national anthem every morning?" talked about patriotism and respect for our country (e.g., "To show patriotism or pride for our country;" "To respect our country"). Two people said they did not know why the national anthem is sung in schools. This might indicate a lack of knowledge about rituals in general, however the person who did not provide an answer to the treaty acknowledgment question answered the question about the national anthem, "to never forget the Canada if a free independent country," indicating that they have at least some ideas about some rituals.

There is some contradiction between the national anthem and the treaty acknowledgment: the acknowledgment says that settler Canada is occupying Turtle Island, while the anthem asserts that the land belongs to settler Canada. Many people have also noted the line in the English translation of Canada's national anthem "our home and native land" - written to emphasize Canadian sovereignty and colonial Canadian 
futurity-rings differently if the word "native" is used to mean Indigenous. The contradiction reveals and highlights debates about land ownership, but through the careless and disrespectful sentiment with which the acknowledgment is conducted, the school board's ritual performance suggests either ambivalence towards the Indigenous claims, or makes an active statement that these claims are meaningless and that the land rightly belongs to settlers.

The way the school board performs the rituals of the anthem and the acknowledgement demonstrate the board's engagement with Article 63's call to action to "build student capacity for understanding, empathy, and mutual respect." There are several problems, however, with their approach. First, the school board's decision to put the anthem and acknowledgement one after another suggests equivalence-that both rituals have equal value in the school setting. However, pairing them also suggests the acknowledgement, and by extension, Indigenous peoples, are being incorporated into Canadian identity, rather than Canada working towards Indigenization. As Vowel (2016) writes, "Many Indigenous peoples do not identify as Canadian because, at no point, did they or their ancestors consent to becoming Canadian. The issue is much more complex than this, of course, but it is important to be aware of the situation" (p. 18). If these practices are "Canadianizing" Indigenous peoples, that's the opposite of Indigenizing.

Second, the school board is making these two rituals apparently equal in their significance to participants, while devaluing one of them. The participation in these rituals is required by the board, although demands for respectful participation in the acknowledgement are limited. This brings me back to questions about using the acknowledgement to fulfill Article 63. When we sing the national anthem and read treaty acknowledgments, is it about settlers and Indigenous peoples, or is it about all people living on Turtle Island (empathetically and respectfully) together? As mentioned, Sweigart-Gallagher \& Lantz (2014) discusses rituals When we sing the national anthem and read treaty acknowledgements, is it about settlers and Indigenous peoples, or is it about all people living on Turtle Island together?

as creating "collective selfconsciousness" (p. 4). That means they are supposed to make all of us feel "unified." If our morning rituals were done differently, could these rituals also contribute towards, as Article 63 mandates, "building student capacity for understanding, empathy and mutual respect"? 
Although this survey produced valuable data from a small sample size-one school, and 27 respondents ${ }^{7}$ - it would be informative to do a similar survey at the end of the school year, and again next year. This would allow me to see what people learn through the school year. Giving this survey to a wider audience ${ }^{8}$ would also be very interesting. A much larger sample size of several hundred respondents from different schools would allow meaningful statistical analysis, not to mention a better sense of themes of concern to responding students. None of the respondents to my survey identified as Indigenous, so it should be noted that my data only reveal a settler perspective and settler ideas. If I did this survey again I would like to ask additional questions about treaties, as well as the meaning of Indigenization. It would be also interesting to know if, by the end of the year, my classmates had memorized the treaty acknowledgement-or even understood some of its meaning - just by listening to it every day.

I must also recognize my position as a settler, and as a student. As a settler, I am far removed from many issues I write about, even though I know about my own education experiences firsthand. Also, my position as a grade 7 youth means that I lack insight into the processes in school administration (in my school or the school board), although it does grant me valuable, informative and relevant lived experiences, as I have seen the execution and student reception of daily rituals firsthand.

C O N C LUS ION According to Simpson (2012), "We need to create a generation of inspired, critical thinkers not only able to interrogate colonialism but also to vision and actualize Indigenous ways of living" (para. 18). Vowel (2016) has similar ideas: "Education is widely seen as a key component to future success not only for the individual children who receive that education, but also for the society to which they belong, as a whole" (p. 276). Although both were talking about Indigenous schools, I think that "creating a generation of inspired, critical thinkers" who understand what it means to live "in-relation" is important for settler schools as well, and that will "benefit the society as a whole" (Simpson, 2012, 2013). These ideas put forward by Simpson and Vowel indicate how important it is to think about how daily rituals in settler schools and settler education systems define the parameters and begin to effect the end result of settler-Indigenous reconciliation.

Performing the treaty acknowledgment every morning

7. I sent the survey to 120 people, but only 27 responded.

8. If you are interested in sending this survey to your school, contact me. 
before classes begin has the potential to be a powerful ritual, making recognition and respect part of the collective consciousness of the community that Sweigart-Gallagher \& Lantz (2014) describe. However, my survey and personal experiences indicate that it is falling short in an extreme way. Students rarely even notice that it is being read, and when it is noticed it is treated with disrespect and indifference. The daily national anthem performance proves that my school board has the ability to craft a strong ritual. This capability must be used for the acknowledgment as well. The fact that I have heard treaty acknowledgments performed with respect and honour in nonschool environments demonstrates that the ritual can be done differently. But if the treaty acknowledgement were handled with the same respect as our national anthem, would that send a message that Indigenous histories, stories, and contemporary lives are as important to remember as settler lives? I think that it is an important thing to do, and although it is not all that is needed, we need to start somewhere, and observing this ritual with respect is a good first step.

The acknowledgment, however, is ultimately not contributing to the Indigenization of the school system. The treaty acknowledgement feels like it is being coopted by a settler institution, and that the board is attempting to assimilate Indigenous practices in the name of reconciliation - rather than finding a way to live and learn together, truly in relationship, the way that Simpson describes. Simpson (2013) describes "living in relation" by saying that "...the word relationship is paramount here. Anishinaabeg political and philosophical traditions emphasize good relationships - with the natural world and with neighbouring nations - as the basis of good governance and a good life" (para. 10). If Simpson's definition of "living in relation" suggests how Article 63 is interpreted for settler schools and students, this should govern the way our morning school rituals are conducted.

Simpson (2014) also believes that the school system is "doing exactly what it was designed to do" and that "The current Canadian education system trains people to uphold colonialism by silencing Indigenous languages, by erasing the history and contemporary reality of Indigenous-state relations and by ignoring Indigenous intellectual traditions." Using the treaty acknowledgement in a disrespectful, unthinking colonial way is directly counter to any form of reconciliation, or ideas about living in relationship, or a "good life" (Simpson, 2013). In the face of spaces where Indigenizing actions feel easy, some thinkers such as Monique Giroux (2017) are of the opinion that "If 'Indigenizing' education feels this good, we aren't doing it right." Fair enough. I don't want Indigenized education to be full of "heartless, robotic apologies." I want it to be meaningful and to foster settlers and 
Indigenous people living in relation. Maybe thinking about how we start each school day is a useful place to begin.

A C K N OW L E D G M E N T S I would like to thank my principal and my vice-principal for helping me get the survey out to the school. I would like to thank my fifthgrade teacher for sparking my interest in Indigenous issues and for working towards adopting the recommendations of the Truth and Reconciliation Commission the day they came out. I would like to thank Christine Sokaymoh Fredrick for taking time out of her day to talk to me. Finally, I would like to thank Tanya Senk and Jarvis Nandee for providing resources and help electronically.

\section{REFERENCES}

Carter, J. (2015). Discarding sympathy, disrupting catharsis: The mortification of Indigenous flesh as survivanceintervention. Theatre Journal, 67(3), 413-433.

Giroux, M. (2017, November 18). If 'Indigenizing' education feels this good, we aren't doing it right. The Conversation. Retrieved from http://theconversation.com/if-Indigenizingeducation-feels-this-good-we-arent-doing-it-right-87166

Mihesuah, D. A., \& Wilson, A. C. (2004). Indigenizing the academy: Transforming scholarship and empowering communities. Lincoln, NE: University of Nebraska Press.

Simpson, L. B. (2012, October 1). Turning inward: Purposely educating our own [Blog post]. Retrieved from https:// www.leannesimpson.ca/writings/turning-inwardpurposefully-educating-our-own

Simpson, L. B. (2013, May 1). Politics based on justice, diplomacy based on love. Briarpatch Magazine. Retrieved from https://briarpatchmagazine.com/articles/view/politicsbased-on-justice-diplomacy-based-on-love

Sweigart-Gallagher, A., \& Lantz, V. P. (2014). Introduction: temporality, youth, and nation. In A. Sweigart-Gallagher \& V. P. Lantz (Eds.), Nationalism and youth in theatre and performance (pp. 1-16). New York, NY: Routledge.

Toronto District School Board. (n.d.). Treaty acknowledgment. Retrieved from https://www.tdsb.on.ca/Portals/O/ Elementary/Treaty\%20AcknowledgementFINAL.pdf

Truth and Reconciliation Commission of Canada. (2015a). Truth and Reconciliation Commission of Canada: Calls to Action. Retrieved from http://www.trc.ca/websites/trcinstitution/ File/2015/Findings/Calls_to_Action_English2.pdf

Truth and Reconciliation Commission of Canada (2015b). What is the TRC. Retrieved from http://www.trc.ca/websites/ trcinstitution/index.php? $\mathrm{p}=10$ 
Tuck, E., \& Yang, K. W. (2012) Decolonization is not a metaphor. Decolonization: Indigeneity, Education \& Society, 1(1), 1-40.

Vowel, C. (2016). Indigenous writes: A guide to First Nations, Métis \& Inuit issues in Canada. Winnipeg, MB: Portage \& Main Press. 